\title{
METROLOGICAL APPROACH FOR THE QUANTIFICATION OF METALLOPROTEINS (EMRP PROJECT HLT05)
}

\author{
Claudia Swart ${ }^{1, a}$, Sabine Zakel ${ }^{1}$, Claudia Frank ${ }^{1}$, Paola Fisicaro ${ }^{2}$, Heidi Goenaga-Infante ${ }^{3}$ \\ ${ }^{1}$ Physikalisch-Technische Bundesanstalt, Bundesallee 100, 38108 Braunschweig, Germany \\ ${ }^{2}$ Laboratoire National de Métrologie et d'Essais, 1, rue Gaston Boissier, 75724 Paris Cedex 15, France \\ ${ }^{3}$ LGC, Queens Road, Teddington, Middlesex, TW11 0LY, UK
}

\begin{abstract}
About $30 \%$ of all proteins contain metals either as cofactor or covalently bound as part of the protein. Some of these metalloproteins such as transferrin (TRF) and haemoglobin (HGB) are regularly measured in clinical laboratories. However, for most of them, no primary reference measurement procedures exist, although directives such as the EC-directive covering in vitro diagnostic medical devices ((IVD-) directive 98/79/EC) and standards such as EN ISO 17511:2003 demand the traceability of results received for analytes in samples of human origin. The EMRP project HLT05 aims at establishing a traceability chain for metalloproteins as is already in place for some inorganic and small organic molecules in biological samples.
\end{abstract}

Environ $30 \%$ de toutes les protéines contiennent des métaux, soit en tant que cofacteur, soit faisant partie de la protéine par liaison covalente. Certaines de ces métalloprotéines, telles que la transferrine (TRF) et l'hémoglobine (HGB), sont régulièrement analysées en laboratoires cliniques. Cependant, pour la plupart d'entre elles, il n'existe pas de méthode de mesure de référence primaire bien que des directives, telles que la directive CE relative aux dispositifs médicaux de diagnostic in vitro (directive (IVD) 98/79/CE), et des normes, telles que l'EN ISO 17511:2003, exigent la traçabilité des résultats pour les analytes dans les échantillons d'origine humaine. Le projet HLT05 de l'EMRP a pour objectif de mettre en place pour les métalloprotéines une chaîne de traçabilité similaire à celle existant déjà pour les molécules inorganiques et les petites molécules organiques dans les échantillons biologiques.

\section{Introduction}

Laboratory diagnostic has become an important part in clinical diagnostic. However, for many analytes, only assays based on immunoreactions exist and no reference measurement procedure is available to provide traceable results. Many of the analytes are proteins and within this group a considerable amount (about $30 \%$ ) consists of metalloproteins. They are defined as "a protein whose function is conferred by a metal" [1]. Metalloproteins are proteins that contain a metal ion either covalently bound as part of the aminoacid backbone (e.g. selenoproteins) or non-covalently bound as a co-factor [1]. Among the latter are such important proteins as haemoglobin (HGB) or transferrin (TRF) which are iron containing proteins responsible for the transport of oxygen and iron, respectively [2]. For these proteins together with the copper containing proteins superoxide dismutase (SOD) and ceruloplasmin (CER) reference measurement procedures with results traceable to the SI are currently developed within the EMRP project HLT05 "Metrology for metalloproteins" (http://www.ptb.de/emrp/metallomics.html). Related to these proteins are the diagnosis and treatment of important diseases such as anemia (HGB [3] and TRF [4]), diabetes (glycated HGB), Wilson's and Menke's disease (CRP) [5] and cancer prevention and treatment (selenoproteins) [6]. Besides metalloproteins, the project deals also with the quantification of adducts of Pt containing drugs for cancer treatment with proteins. Due to the presence of sulphur and nitrogen containing binding sites in proteins, the Pt in the drugs binds to proteins instead of targeted DNA. This is thought to be responsible for the severe side effects of these drugs. A special challenge is the different concentration ranges for these proteins. For HGB and TRF, for example, the concentration in the blood is in the range of some $\mathrm{mg} / \mathrm{L}$ while SOD and CER are present only in the $\mu \mathrm{g} / \mathrm{L}$ range [2].

\footnotetext{
a Corresponding author: claudia.swart@ptb.de
} 
The EMRP project HLT05 follows a new approach using isotope dilution inductively coupled plasma mass spectrometry (ID-ICP-MS) for the quantification of the proteins. Species specific IDMS was chosen because in this case the spike can be added to the biological samples before any sample treatment. Thus the spike accounts for any loss or changes in the concentration or conformation of the protein. In contrast to IDMS approaches with organic MS where the labelled protein is produced using either ${ }^{13} \mathrm{C}$ or ${ }^{15} \mathrm{~N}$ labelled amino acids $[7,8]$, the metal contained within these proteins is used to produce the spike. For this purpose the metal with natural abundance is removed from the protein and replaced by the metal enriched in one isotope.

As proteins show a great number of genetic variations and many of them do not influence the function of the protein, the approach using the metal content for the quantification simplifies the determination considerably. However, a complete saturation of the metalloprotein under investigation has to be ensured to receive sensible results. Besides, the metal is essential for the function of most metalloproteins. So as long as the metal is incorporated correctly into the protein it is assumed to be functional, at least in the case of coordinative bound metals. Therefore, the quantification of the proteins via the metal content gives in most cases the amount of active protein. This is in contrast to some immunoassays where it has to be verified that the detected part of the protein is really correlated with the function and that the assay gives the concentration of the active protein.

\section{Production metalloproteins \\ of isotopically \\ labelled}

In order to receive isotopically labelled spike material the naturally incorporated metals have to be removed. This can be achieve by reducing the $\mathrm{pH}$ as in the case of TRF [9] or by adding chelating agent such as ethylendiamintetraacetate (EDTA) as the most successful way for SOD [10].

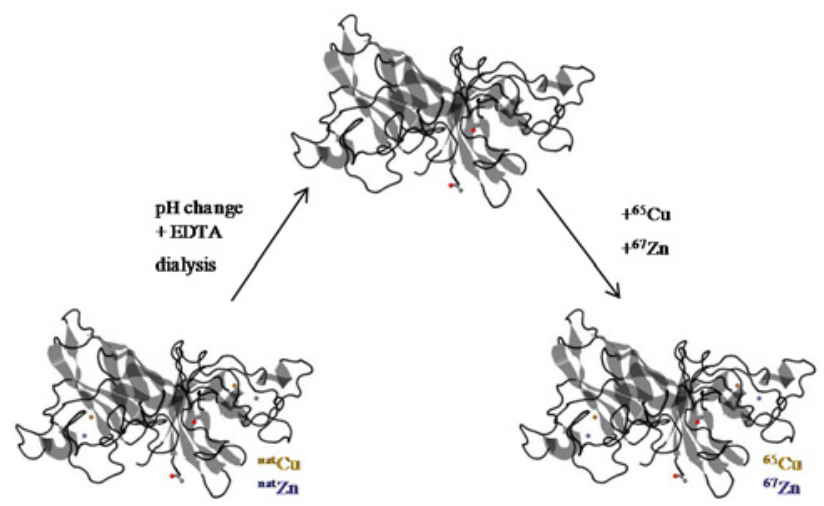

Figure 1. Demetallation and remetallation in order to produce an isotopically enriched spike for metalloprotein quantification with SOD as an example [10] (SOD structure according to $10.2210 / \mathrm{pdb} 2 \mathrm{sod} / \mathrm{pdb}$ ).

The released metals or the EDTA complexes of the metals have to be removed from the solution by dialysis or filtration with a centrifugal filter with a cut-off smaller than the protein investigated. Otherwise the metal will be incorporated again during the remetallation process reducing the isotopical enrichment of the investigated metal in the spike. EDTA has to be removed after the demetallation because any excess will reduce the amount of isotopically enriched metal which can be incorporated into the protein. In the case of TRF and SOD the respective metals are incorporated spontaneously when the $\mathrm{pH}$ is increased. As only the metal is detected in ICP-MS, a complete saturation of the protein has to be ensured for the successful application of IDMS for the quantification of the metalloproteins. A cost and time saving method to determine the iron saturation in TRF was developed by Frank et al. $[11,12]$ using Raman spectrometry. While the free coordination sites in apo-TRF are loaded with $\mathrm{Fe}^{3+}$ ions, additional vibration modes from the coordination partners emerge in the Raman Spectra of the protein. The peak intensities of three of the four modes are accessible for quantitative analysis (Figure 2). Once a calibration model is established from a set of reference mixtures, spectra of TRF samples with unknown iron saturation can serve for the prediction.

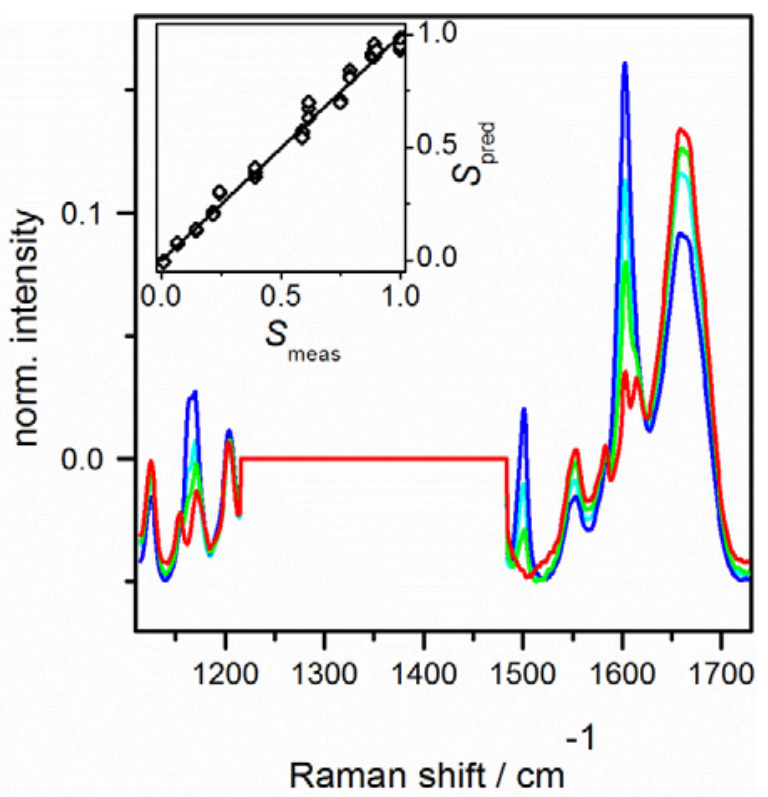

Figure 2. Selected Raman spectra from calibration solutions for iron saturation from $0.0 \mathrm{~mol} / \mathrm{mol}$ (red) up to $1.0 \mathrm{~mol} / \mathrm{mol}$ (blue) after data pretreatment and predicted versus measured plot from cross validation of the calibration model (inset) [11]. Reproduced with permission of The Royal Society of Chemistry

Furthermore, the stability of the spike in the sample matrix against metal exchange has to be ensured. 


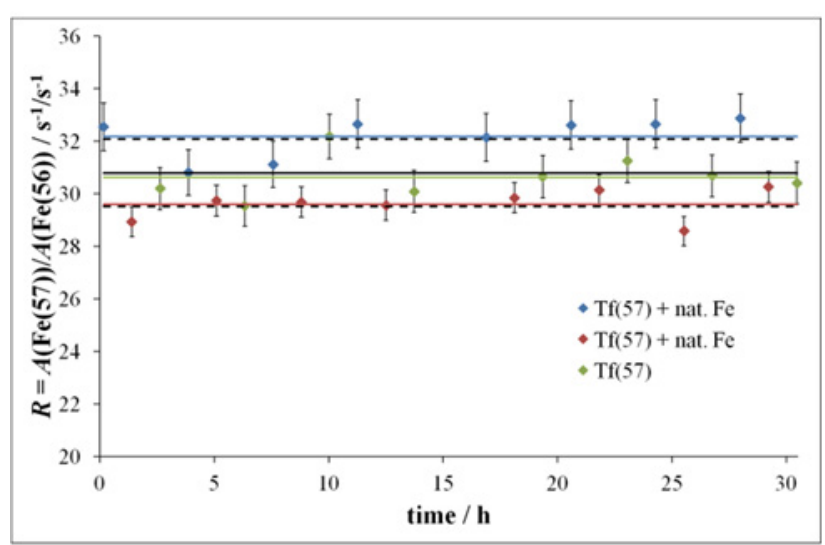

Figure 3. Stability of TRF containing ${ }^{57} \mathrm{Fe}$ against the exchange of enriched $\mathrm{Fe}$ with natural $\mathrm{Fe}$ [12].

The spike has at least to be stable over the duration of production, sample preparation and measurement. For the TRF spike it was shown to last at least $30 \mathrm{~h}$ which is time enough for the determination of TRF in serum.

\section{Quantification of metalloproteins}

With the isotopically labelled metalloprotein available as spike material it can be added to clinical samples (serum, whole blood, haemolysate, etc.) before any further sample treatment. The preferable abundance ratio of reference isotope (usually the naturally most abundant isotope) and spike isotope (the one enriched in the spike material) is 1. Should any transformation or losses occur, it can be assumed that the spike is affected in the same way as the analyte; thus the isotope ratio in the analyte will not be changed [13].

When using the metal for the quantification, the sample preparation usually includes a separation step to ensure that the protein under investigation is separated from all other molecules containing the same metal. Especially in serum samples albumin (ALB) can cause considerable interferences because it tends to bind many metals unspecifically. As ALB concentration is very high in serum and whole blood samples, sometimes more metal (e.g. $\mathrm{Cu}$ ) is bound to ALB then to the investigated protein (e.g. SOD). Therefore, a high performance liquid chromatography (HPLC) can be coupled to ICP-MS. For many proteins an ion-exchange column is used with some kind of buffer as eluent.

In order to avoid having to determine all isotope abundances in spike and sample, double IDMS is applied [14].

$$
w_{\mathrm{x}}=w_{\mathrm{z}} \cdot \frac{m_{\mathrm{yx}}}{m_{\mathrm{x}}} \cdot \frac{m_{\mathrm{z}}}{m_{\mathrm{yz}}} \cdot \frac{R_{\mathrm{y}}-R_{\mathrm{bx}}}{R_{\mathrm{bx}}-R_{\mathrm{x}}} \cdot \frac{R_{\mathrm{bz}}-R_{\mathrm{z}}}{R_{\mathrm{y}}-R_{\mathrm{bz}}}
$$

Therefore, a reference material with a known amount of analyte is treated in the same way as the sample. However, for most proteins this approach is difficult as no reference material or even purified protein is available. In case of TRF the reference solution was prepared dissolving the purified protein in buffer. In other cases the isolation and characterization of the protein might have to be done before applying IDMS.

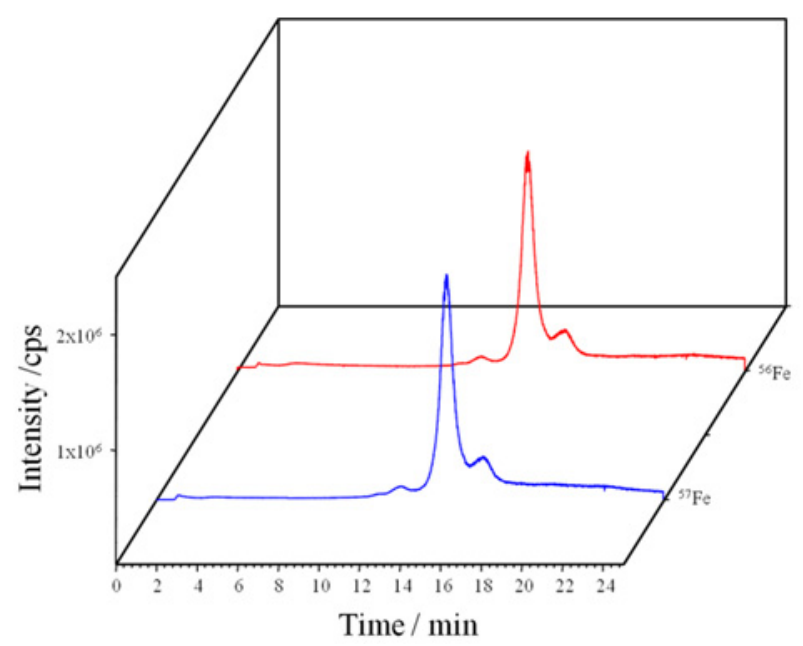

Figure 4. Chromatogram of a mixture of natural TRF and ${ }^{57} \mathrm{Fe}-$ TRF using HPLC-ICP-MS. It can be seen that the natural protein and the isotopically labelled protein behave identically indicating that the protein has been reconstituted successfully during spike production.

\section{Alternative Approaches}

As ICP-MS can only detect the metal in the protein, it has to be verified that the peak in the chromatogram actually corresponds to the protein under investigation. Therefore, complementary methods are applied in the project HLT05 to verify the protein identity and the peak purity after separation. Besides the already mentioned use of Raman spectrometry also other complementary methods like organic MS and optical methods will be used. Especially organic MS enables the identification of the protein under investigation and allows an estimation regarding the peak purity. As ICP-MS detects only the metal, it is not necessary to separate the metalloprotein completely from all other proteins but it has to be ensured that no other protein carrying the same metal is "hidden" in the same peak. Furthermore, new separation techniques like affinity chromatography are developed which enables the retention of a specific protein on a column by the help of immobilized antibodies which are specific for this proteins [15]. This separation method will then be coupled to different detection methods such as ICP-MS and organic MS.

Another intention of the EMRP project is to link methods used in routine laboratories to the developed primary reference methods. As an example, haemoglobin will be investigated using ID-ICP-MS as well as organic IDMS via characteristic ${ }^{13} \mathrm{C}$ labelled peptides and the alkaline haematin detergent (AHD) method [16]. The latter was developed by Heuck at al. [16] because the WHO reference method [17]used up to now is not allowed anymore in many developing countries due to the restrictions in the use of potassium cyanide. In the AHD method haematin is released from all haemoglobin variants and detected with UV/VIS [16]. It enables the use of pure haematin chloride as calibration standard which is 
a well-defined compound. This method can easily be used in clinical laboratories world-wide as it requires only nontoxic reagents. Furthermore, it does not suffer from interferences from triglycerides and bilirubin as is the cyanide method and the kinetics are faster and comparable for haemiglobin, carboxyhaemoglobin, sulfoxyhaemoglobin and other modifications.

\section{Conclusion}

The identification and characterisation of biomarkers has made considerable progress in the past and still is. This will improve the clinical diagnostic and the treatment of different diseases. However, to ensure the individual treatment and lower the costs for the healthcare systems it is crucial to establish a traceability chain for important biomarkers. This will reduce the number of multiple analyses and lay the basis for an effective treatment of patients all over the world. As people become more and more mobile, national systems for quality assurance in laboratory diagnostics are no longer sufficient. The great challenge of the future will be to establish an international accepted traceability chain for these analytes. Therefore, the International Federation of Clinical Chemistry (IFCC) has started to establish international reference systems for the most important biomarkers. In the field of metalloproteins, such a system is only available for the determination of glycated HGB (HbA1c) [18].

In the field of metalloproteins, the EMRP project HLT05 will contribute to these challenges by developing reference measurement procedures that can hopefully be applied to a great variety of metalloproteins.

\section{Acknowledgement}

This research was undertaken within the projects EMRP HLT05. The EMRP is jointly funded by the EMRP participating countries within EURAMET and the European Union.

\section{References}

1. S. Mounicou, J. Szpunar, and R. Lobinski, Chem. Rev. Soc. 38, 4, 1119 (2009).

2. Klinisches Wörterbuch - Pschyrembel ${ }^{\circledR}$, Walter de Gruyter GmbH\&Co. KG, Berlin (2007), 261 ed.

3. B. Shah, G. Puranik, and V. Shah, Indian J. Pathol. Micr. 54, 4, 764 (2011).

4. G. De Jong, J. P. Van Dijk, and H. G. Van Eijk, Clin. Chim. Acta 190, 1-2, 1 (1990).

5. C. M. Mak, C.-W. Lam, and S. Tam, Clin. Chem. 54, 8, 1356 (2008).

6. G. Ballihaut, L. E. Kilpatrick, and W. C. Davis, Anal. Chem. 83, 22, 8667 (2011).

7. C. G. Arsene, R. Ohlendorf, W. Burkitt, C. Pritchard, A. Henrion, G. O'Connor, D. M. Bunk, and B. Güttler, Anal. Chem. 80, 11, 4154 (2008).

8. C. G. Arsene, D. Schulze, J. Kratzsch, and A. Henrion, J. Mass. Spectrom. 47, 12, 1554 (2012).

9. E. Del Castillo Busto, M. Montes-Bayón, J. I. Garcia Alonso, J. A. Caruso, and A. Sanz-Medel, Analyst 135, 7, 1538 (2010).
10. C. Deitrich, S. Braukmann, A. Raab, C. Munro, B. Pioselli, E. Krupp, J. Thomas-Oates, and J. Feldmann, Anal. Bioanal. Chem. 397, 8, 3515 (2010).

11. C. Frank, O. Rienitz, R. Jährling, D. Schiel, and S. Zakel, Metallomics 4, 12, 1239 (2012). http://dx.doi.org/10.1039/C2MT20183F

12. C. Frank, PhD thesis, Freie Universität, Berlin (2013). urn:nbn:de:kobv:188fudissthesis000000094010-9

13. C. F. Harrington, D. S. Vidler, M. J. Watts, and J. F. Hall, Anal. Chem. 77, 13, 4034 (2005).

14. M. Sargent, C. Harrington and R. Harte, Eds., Guidelines for achieving high accuracy in isotope dilution mass spectrometry (IDMS), Royal Society of Chemistry, Cambridge (2002).

15. H. Rehm, Der Experimentator Proteinbiochemie/Proteomics Spektrum Akademischer Verlag, München (2006), 5 ed.

16. C. C. Heuck, H. Reinauer, and W. G. Wood, Clin. Lab. 54, 7+8, 255 (2008).

17. World Health Organization-WHO, Blood Safety and Clinical Technology: Guidelines on Standard Operating Procedures for Haematology Chapter 7 Haemoglobinometry, WHO (1965). http://209.61.208.233/en/Section10/Section17/Secti on53/Section480_1728.html

18. J.-O. Jeppsson, U. Kobold, J. Barr, A. Finke, W. Hoelzel, T. Hoshino, K. Miedema, A. Mosca, P. Mauri, R. Paroni, L. Thienpont, M. Umemoto, and C. Weykamp, Clin. Chem. Lab. Med. 40, 1, 78 (2002). 